Supporting Information

\title{
Carboxylic Acid-Terminated Carbon Nanoflakes for Selective Adsorption of Water-Soluble Cationic Dyes
}

Chumki Dalal, Anjali Kumari Garg and Sumit Kumar Sonkar*

${ }^{7}$ Department of Chemistry, Malaviya National Institute of Technology, Jaipur, Jaipur-302017, India.

*To whom correspondence should be addressed: sksonkar.chy@mnit.ac.in

Table S1. Comparative Data of Pseudo-first-order and Pseudo-second-order models.

\begin{tabular}{|c|c|c|c|c|c|c|c|c|}
\hline \multirow[b]{2}{*}{ Dye } & \multirow[b]{2}{*}{$\begin{array}{l}\text { Conc. } \\
\text { (ppm) }\end{array}$} & \multirow[b]{2}{*}{$\begin{array}{c}\text { qe }(\text { experimental }) \\
\left(\mathrm{mg} \mathrm{g}^{-1}\right)\end{array}$} & \multicolumn{3}{|c|}{ Pseudo-first order kinetics } & \multicolumn{3}{|c|}{ Pseudo-second order kinetics } \\
\hline & & & $\mathbf{R}^{2}$ & $\begin{array}{c}\text { qe(graphical) } \\
\left(\mathrm{mg} \mathrm{g}^{-1}\right)\end{array}$ & $\begin{array}{c}\mathrm{K}_{1} \\
\left(\mathrm{~min}^{-1}\right)\end{array}$ & $\mathbf{R}^{2}$ & $\begin{array}{c}\text { qe(graphical) } \\
\left(\mathrm{mg} \mathrm{g}^{-1}\right)\end{array}$ & $\begin{array}{c}\mathrm{K}_{2} \\
\left(\mathrm{mg}^{-1} \mathrm{~g}\right. \\
\left.\mathrm{min}^{-1}\right)\end{array}$ \\
\hline \multirow{4}{*}{ MB } & 20 & 39.69386 & 0.6771 & 3.371508 & 0.06509 & 0.9999 & 39.74563 & 0.139433 \\
\hline & 40 & 79.48173 & 0.5835 & 9.260426 & 0.05186 & 0.9999 & 79.61783 & 0.042868 \\
\hline & 60 & 115.2477 & 0.8185 & 44.57753 & 0.04269 & 0.9997 & 116.8224 & 0.003918 \\
\hline & 80 & 151.929 & 0.9579 & 70.93188 & 0.06682 & 0.9999 & 154.0832 & 0.004133 \\
\hline \multirow{4}{*}{ CV } & 20 & 39.68568 & 0.9226 & 32.2333 & 0.04709 & 0.9785 & 43.84042 & 0.002017 \\
\hline & 40 & 79.77235 & 0.6243 & 8.61246 & 0.07295 & 0.9999 & 80.06405 & 0.035862 \\
\hline & 60 & 116.3914 & 0.9004 & 107.8056 & 0.07366 & 0.9992 & 120.048 & 0.002201 \\
\hline & 80 & 148.9011 & 0.8922 & 70.13837 & 0.04252 & 0.9991 & 151.5152 & 0.002228 \\
\hline \multirow{4}{*}{ RhB } & 20 & 38.11792 & 0.8797 & 15.77364 & 0.04646 & 0.9994 & 38.75969 & 0.010676 \\
\hline & 40 & 78.34539814 & 0.7474 & 28.63844 & 0.03481 & 0.9994 & 78.98894 & 0.005442 \\
\hline & 60 & 111.154015 & 0.9189 & 66.62501 & 0.0301 & 0.9948 & 114.5475 & 0.001318 \\
\hline & 80 & 137.677212 & 0.9400 & 79.85081 & 0.04598 & 0.9984 & 141.2429 & 0.001814 \\
\hline
\end{tabular}


Table S2. Comparative Data of Langmuir and Freundlich Isotherm Model.

\begin{tabular}{|l|c|l|l|l|l|l|l|}
\hline \multirow{2}{*}{ Dye } & \multicolumn{3}{|c|}{ Langmuir } & \multicolumn{3}{c|}{ Freundlich } \\
\cline { 2 - 8 } & $\begin{array}{l}\mathbf{q} \mathbf{m}\left(\mathbf{m g} \mathbf{g}^{\mathbf{1}}\right. \\
\text { 1 }\end{array}$ & $\mathbf{K}_{\mathbf{L}}$ & $\mathbf{\mathbf { R } _ { \mathbf { L } }}$ & $\mathbf{R}^{\mathbf{2}}$ & $\mathbf{K}_{\mathbf{F}}$ & $\mathbf{1 / n}$ & $\mathbf{R}^{\mathbf{2}}$ \\
\hline MB & 148.15 & 2.14 & $\begin{array}{l}0.0228- \\
0.0031\end{array}$ & 0.9995 & 83.83203 & 0.1776 & 0.6336 \\
\hline CV & 132.45 & 12.42 & $\begin{array}{l}0.0040- \\
0.0005\end{array}$ & 0.9998 & 85.61897 & 0.1407 & 0.4924 \\
\hline RhB & 117.65 & 15.83 & $\begin{array}{l}0.0031- \\
0.0004\end{array}$ & 0.9980 & 65.54657 & 0.1781 & 0.3974 \\
\hline
\end{tabular}

Table S3. Various thermodynamic parameters $\left(\Delta \mathrm{G}^{0}, \Delta \mathrm{H}^{0}\right.$ and $\left.\Delta \mathrm{S}^{0}\right)$ for the adsorption of $\mathrm{CV}, \mathrm{MB}$ and $\mathrm{RhB}$ on CNFs at different temperatures.

\begin{tabular}{|c|c|c|c|c|c|}
\hline Dye & Temperature $(\mathrm{K})$ & $\Delta \mathrm{G}^{0}\left(\mathrm{~J} \mathrm{~mol}^{-1}\right)$ & $\mathrm{R}^{2}$ & $\Delta \mathrm{H}^{0}\left(\mathrm{KJ} \mathrm{mol}^{-1}\right)$ & $\Delta \mathrm{S}^{0}\left(\mathrm{~J} \mathrm{~mol}^{-1} \mathrm{~K}^{-1}\right)$ \\
\hline \multirow{4}{*}{ MB } & 293 & -3726.24 & \multirow{4}{*}{0.91963} & \multirow{4}{*}{12.18} & \multirow{4}{*}{54.38} \\
\hline & 303 & -3933.52 & & & \\
\hline & 313 & -4888.83 & & & \\
\hline & 323 & -5411.75 & & & \\
\hline \multirow{4}{*}{$\mathrm{CV}$} & 293 & -3412.77 & \multirow{4}{*}{0.92292} & \multirow{4}{*}{21.87} & \multirow{4}{*}{85.67} \\
\hline & 303 & -3882.37 & & & \\
\hline & 313 & -4792.57 & & & \\
\hline & 323 & -5997.11 & & & \\
\hline \multirow{3}{*}{$\mathrm{RhB}$} & 293 & -3471.1 & \multirow{3}{*}{0.97177} & \multirow{3}{*}{12.9} & \multirow{3}{*}{55.27} \\
\hline & 303 & -3804.31 & & & \\
\hline & 313 & -4517.58 & & & \\
\hline
\end{tabular}




\begin{tabular}{|l|l|l|l|l|l|}
\hline & 323 & -4907.05 & & & \\
\hline
\end{tabular}

Table S4. Comparative table of previous studies showing maximum Langmuir adsorption capacities for CV, MB and RhB.

\begin{tabular}{|c|c|c|c|}
\hline Adsorbent & Adsorbate & $\begin{array}{l}\text { Adsorption Capacity } \\
\mathbf{q m}_{\mathbf{m}}\left(\mathbf{m g ~ g}^{-1}\right)\end{array}$ & Reference \\
\hline Ephedra strobilacea char (ESC) & MB & 31.15 & 16 \\
\hline $\begin{array}{l}\text { Gold nanoparticle loaded on activated } \\
\text { carbon (Au-NP-AC) }\end{array}$ & MB & 40.65 & 17 \\
\hline $\begin{array}{l}\text { Red mud-activated graphite } \\
\text { composites (RMGC) }\end{array}$ & MB & 89.28 & 33 \\
\hline Activated carbon of Rice husk & MB & 129.5 & 18 \\
\hline $\begin{array}{lcc}\text { Sewage Sludge } & \text { Based } & \text { Granular } \\
\text { Activated Carbon (SSGAC) } & \\
\end{array}$ & MB & 131.8 & 19 \\
\hline $\begin{array}{l}\text { Dithiocarbamate-functionalized } \\
\text { graphene oxide }\end{array}$ & MB & 137 & 34 \\
\hline watermelon (Citrullus) rind (CWMR) & MB & 200 & 20 \\
\hline Onion-like nano carbon & MB & 247 & 42 \\
\hline GO/CS sponge & MB & 275.5 & 35 \\
\hline MWCNT hydrogel & MB & 525.41 & 45 \\
\hline Ricinus Communis Pericarp Carbon & $\mathrm{CV}$ & 48.00 & 21 \\
\hline Magnetically modified activated carbon & $\mathrm{CV}$ & 57.8 & 22 \\
\hline $\begin{array}{l}\text { Activated carbon derived from } \\
\text { pomegranate peels }\end{array}$ & $\mathrm{CV}$ & 76.92 & 23 \\
\hline Diatomite earth \& carbon & $\mathrm{CV}$ & 87.05 & 24 \\
\hline f-MWNTs & $\mathrm{CV}$ & 90.52 & 40 \\
\hline $\begin{array}{l}\text { Carrageenan/multi-walled } \begin{array}{r}\text { carbon } \\
\text { nanotube hybrid hydrogel nanocomposite }\end{array}\end{array}$ & $\mathrm{CV}$ & 118 & 46 \\
\hline EDTA-GO/cornob & $\mathrm{CV}$ & 203 & 36 \\
\hline $\begin{array}{l}\text { Activated carbons obtained from } \\
\text { lignocellulosic waste }\end{array}$ & $\mathrm{RhB}$ & 39.73 & 25 \\
\hline
\end{tabular}




\begin{tabular}{|l|l|l|l|}
\hline MWCNT-COOH & $\mathrm{RhB}$ & 42.68 & 41 \\
\hline P-CZIF-867 & $\mathrm{RhB}$ & 137.10 & 26 \\
\hline PLC/AC & $\mathrm{RhB}$ & 149.57 & 27 \\
\hline Mesoporous graphite nanoflakes & $\mathrm{RhB}$ & 150 & 44 \\
\hline Woodchips Derived Activated Carbon & $\mathrm{RhB}$ & 189.80 & 28 \\
\hline TA-G & $\mathrm{RhB}$ & 201.21 & 37 \\
\hline Ni doped FeO(OH)-NWs-AC & $\mathrm{RhB}$ & 210.17 & 29 \\
\hline $\begin{array}{l}\text { Poly(4,40-oxybisbenzenamine) } \\
\text { (POBBA) }\end{array}$ & $\mathrm{MB}$ & 17.3 & 39 \\
\hline \multirow{2}{*}{ Carbon Nanoflakes (CNFs) } & $\mathrm{CV}$ & 13.1 & \\
& $\mathrm{RhB}$ & 18.2 & This work \\
\hline
\end{tabular}

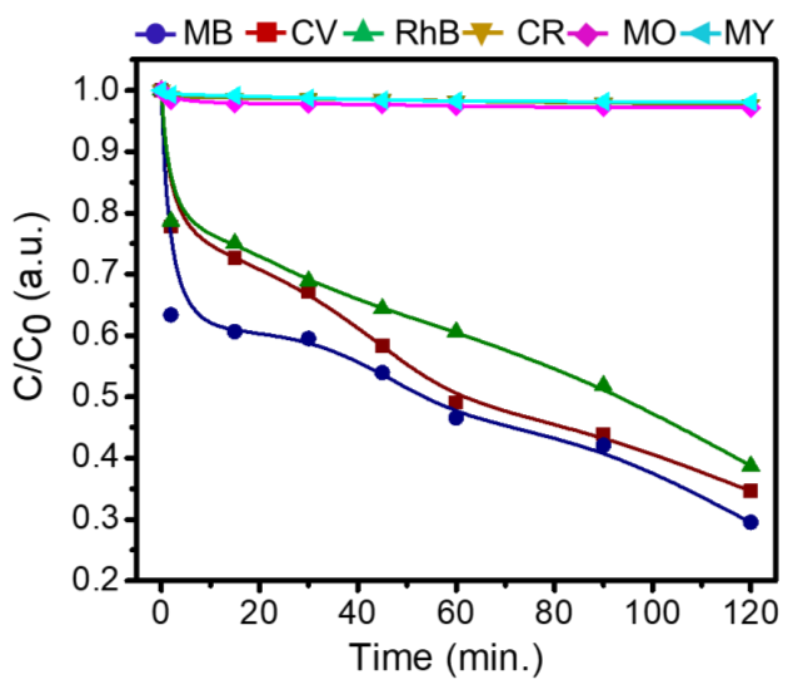

Figure S1. The plot of $\mathrm{C} / \mathrm{C}_{0}$ vs time for $\mathrm{CNFs}$ for $100 \mathrm{mg} \mathrm{L}^{-1}$ concentration of dyes $\mathrm{MB}, \mathrm{CV}$, $\mathrm{RhB}, \mathrm{CR}, \mathrm{MO}$ and $\mathrm{MY}$, the loading of CNFs is $0.4 \mathrm{mg} / \mathrm{mL}$. 
a)

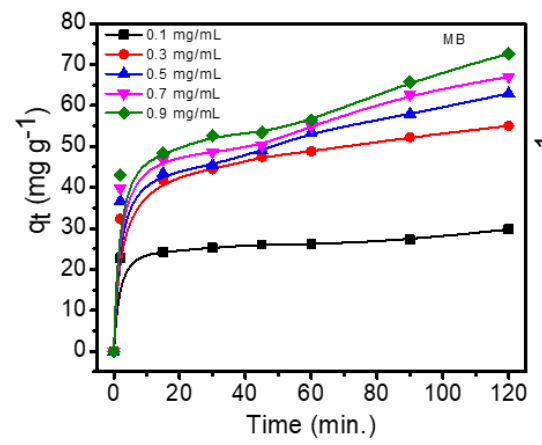

b)

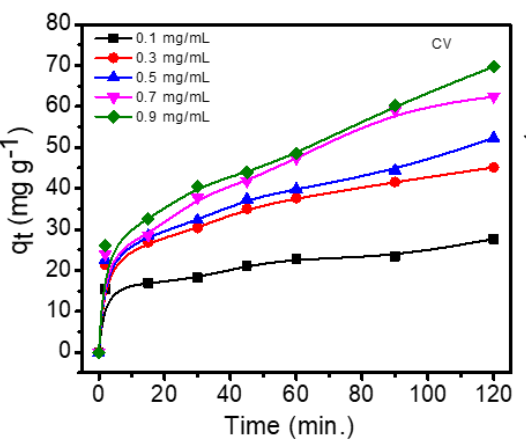

c)

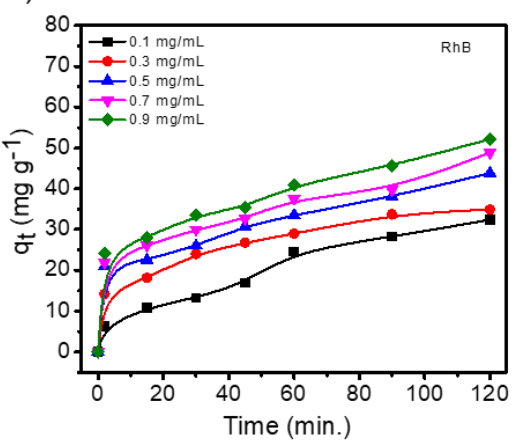

Figure S2. The effects of the loading of the adsorbent in range of $0.1-0.9 \mathrm{mg} / \mathrm{mL}$ on the adsorption efficiency towards a) $\mathrm{MB}$, b) $\mathrm{CV}$, and c) $\mathrm{RhB}$ dye have been studied for fixed amount of dye $(100 \mathrm{mg} / \mathrm{L})$. results shows that $\mathrm{q}_{\mathrm{t}}$ value increases with increasing the amount of adsorbent from $0.1-0.9 \mathrm{mg} / \mathrm{mL}$ due to the presence of more surface area of absorbent for a fixed amount of adsorbate.

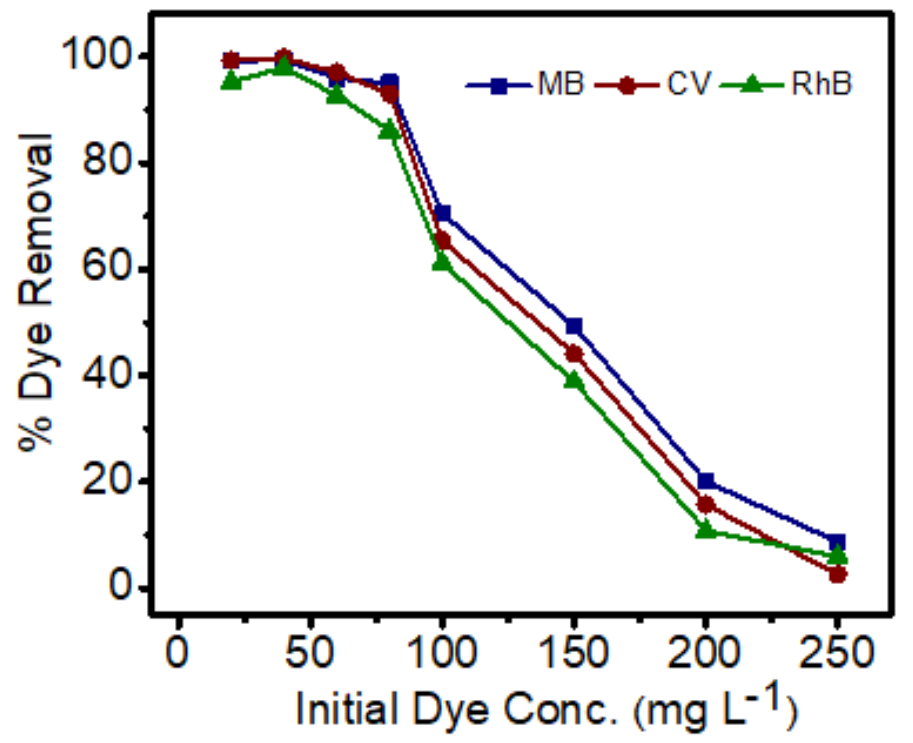

Figure S3. Effect of initial dye concentration on adsorption. Results shows that the percentage of removal of dyes significantly decreases with increasing the concentration of dyes from 80 to $250 \mathrm{mg} \mathrm{L}^{-1}$ due to unavailability of unoccupied surface on adsorbent. 


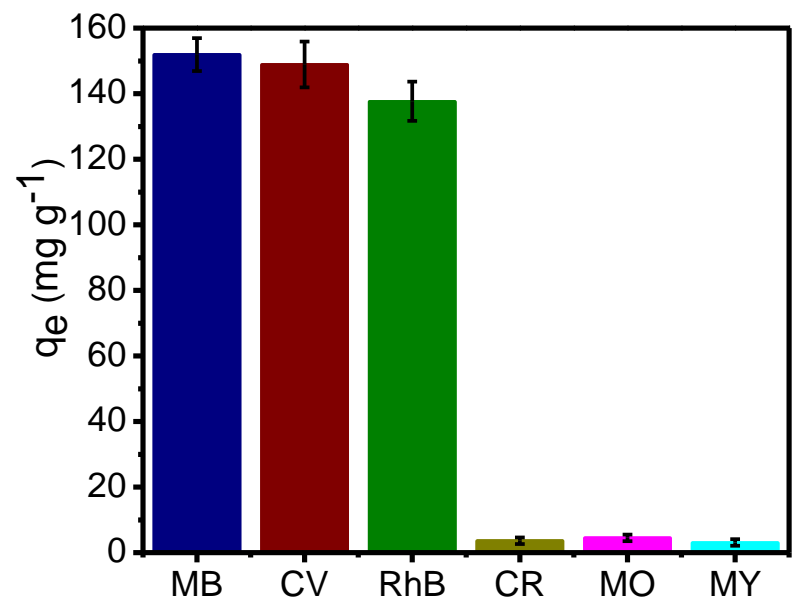

Figure S4. Adsorption capacity at steady state of CNFs towards six dyes. In all cases, the loading of CNFs is $0.5 \mathrm{mg} / \mathrm{mL}$. Results show the higher adsorption capacity of CNFs towards cationic dyes (MB, CV, and RhB) over anionic dyes (CR, MO, and MY).

a)

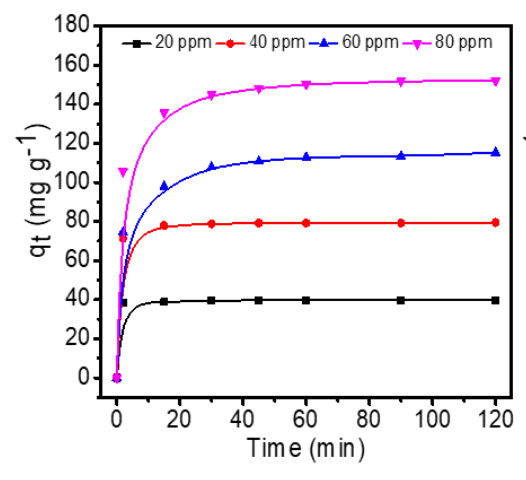

b)

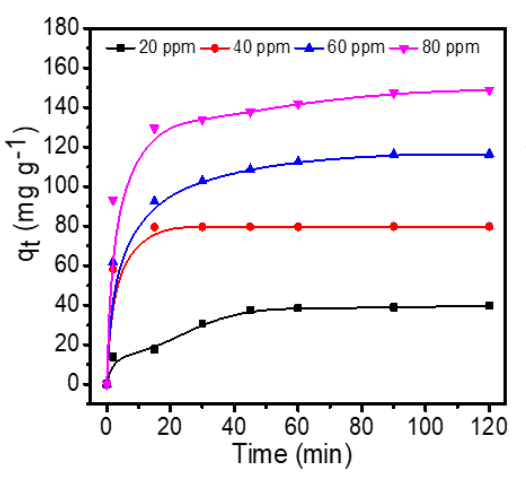

c)

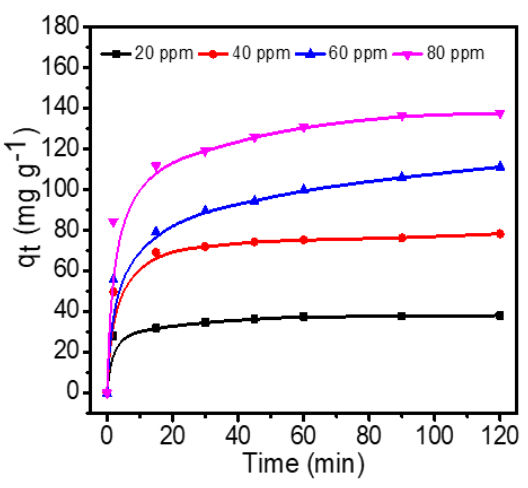

Figure S5. Plot of adsorption capacity at time $\mathrm{t}\left(\mathrm{q}_{\mathrm{t}}\right)$ vs time plot for adsorption of 20-80 ppm a) $\mathrm{MB}$, b) $\mathrm{CV}$ and c) RhB dyes on CNFs adsorbent. Results show that adsorption capacity becomes maximum for $80 \mathrm{ppm}$ of dyes. 


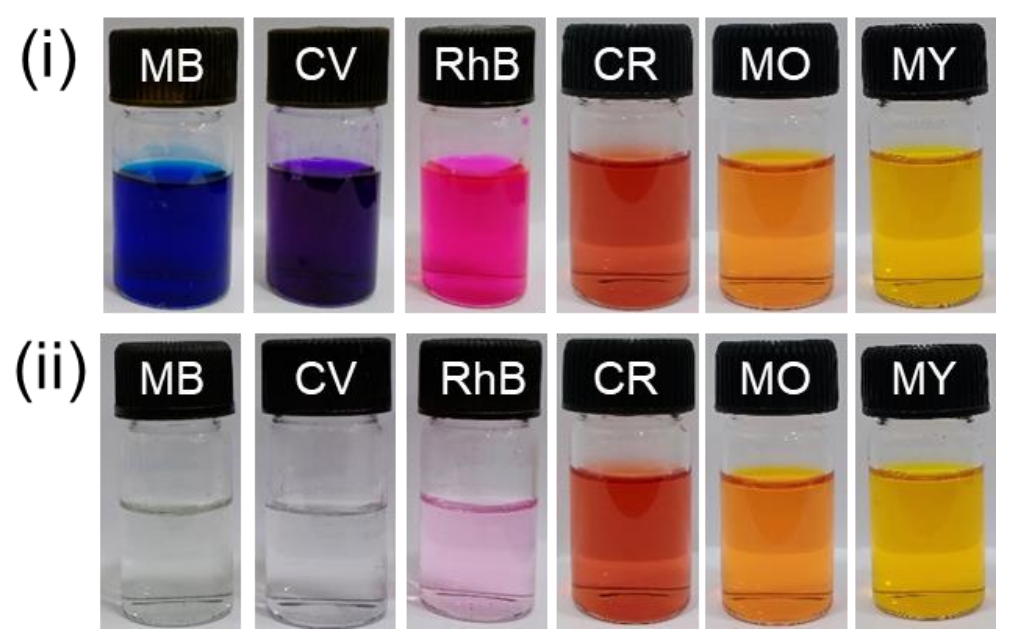

Figure S6. Photographic images of dyes (i) before and (ii) after adsorption by CNFs adsorbent. Results indicates the selective and enhanced adsorption of group of dyes having cationic charge (MB, CV and $\mathrm{RhB}$ ) compared to anionic dyes ( $\mathrm{CR}, \mathrm{MO}$ and $\mathrm{MY}$ ).

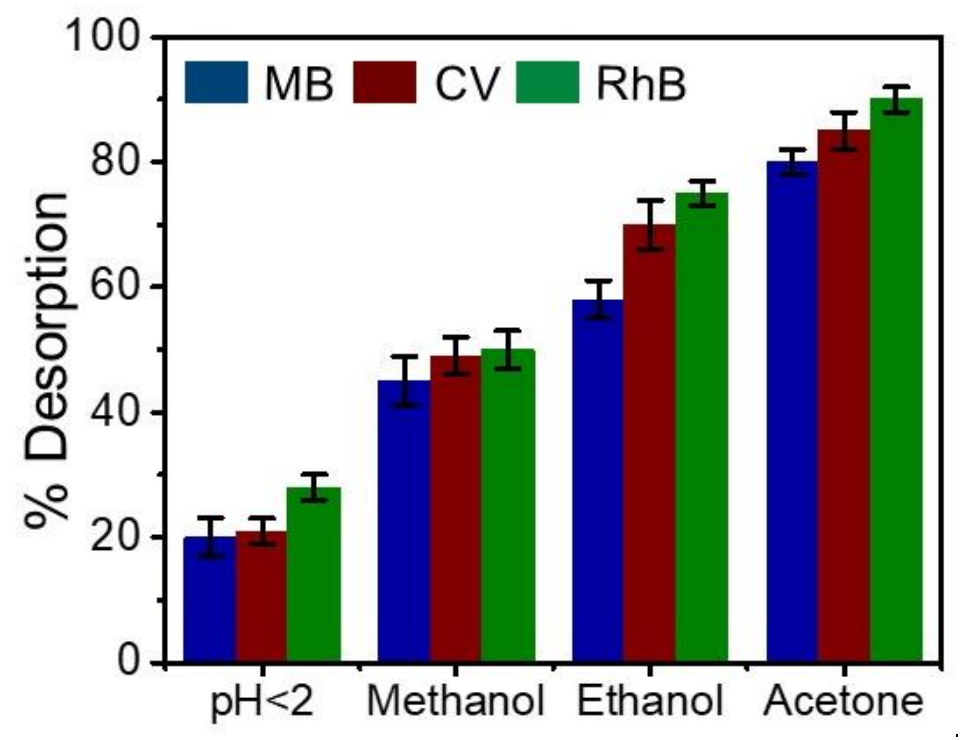

Figure S7. Desorption study of $\mathrm{MB}, \mathrm{CV}$, and $\mathrm{RhB}$ dyes from $\mathrm{CNFs}$ surface by lowering the solution $\mathrm{pH}$ and by adding different solvent. No significant desorption has been observed by lowering the $\mathrm{pH}$ of solutions. Additionally, results show that maximum dye desorption occurs in acetone as compared to other solvent. 